УДК 069.68

DOI: https://doi.org/10.26642/jen-2021-3(97)-8-11

М.Е. Кругляк, к.і.н., доц.

Державний університет «Житомирська політехніка»

\title{
«Ніч музеїв» як успішний приклад музейної комунікації
}

У статті розглянуто всесвітньо відому акцію «Ніч музеїв» як один з успішних прикладів музейної комунікації. Цей захід, як правило, проводиться в Міжнародний день музеїв і є одним зі шляхів створення позитивного образу музею, його популяризаџї та реклами.

Автор подає історію виникнення иієё акції, розповідає про особливості ї̈ проведення в декількох країнах світу, зокрема акцентує увагу на досвіді сусіда України - Польщі. У тексті продемонстровано ступінь залучення музеїв Украӥни до «Ночі музеїв», показано найцікавіші атракції, щчо пропонувалися відвідувачам у 2017-2021 роках. Доведено, щзо акція «Ніч музеїв з кожним роком набуває все більшої популярності у світі та в Україні, щуо до ї̈ проведення все активніше долучаються не стільки музеї, скільки установи сфери культури та освіти, зокрема, мистецькі галереї, Академії наук, університети, бібліотеки, засоби масової інформації.

Наголошено на тому, щьо найчастіше у «Ніч музеїв» пропонується вільний вхід до установ або ж встановлюється помірна ичіна за квиток. Серед найпопулярніших дійств - презентації книжск та колекиій одягу, майстер-класи та квести, театралізовані вистави, концерти, перегляди кінострічок.

Звернено увагу на труднощі в проведенні «Ночі музеїв» в Україні і світі. Окрім обмежень у музеях, пов'язаних із COVID-19, в Украӥні до світової пандемії додаються економічні труднощі: недостатнє фінансування з боку держави, низька залученість спонсорів (особливо в провіниії), пасивність пересічних громадян, нерозвиненість інфраструктури, зокрема транспортної, недостатнє використання можливостей реклами.

Ключові слова: відвідувач; Міжнародний день музеїв; музей; музейна акиія; музейна комунікація; «Ніч музеїв.

Постановка проблеми. Тісний взаємозв'язок між сучасним музеєм і відвідувачем є невід'ємною умовою успішного функціонування цієї культурно-освітньої установи. Поряд із відомими формами музейної комунікації - експозиційно-виставковою, просвітницько-освітньою та видавничою, в умовах інформаційного суспільства та панування ринкових відносин, коли музей може і повинен заробляти, виникають нові способи взаємодії музею і суспільства, метою яких є розширення сфери впливу закладів культури в середовищі громадськості. Одним зі способів популяризації культурної спадщини є організація різноманітних музейних акцій. Розглянемо детальніше «Ніч музеїв» як приклад вдалого просування іміджу музею серед реальних і потенційних відвідувачів.

Аналіз останніх досліджень та публікацій. Історія проведення акції «Ніч музеїв» охоплює лише декілька десятиліть, а тому ця проблема не набула комплексного вивчення. Варто виокремити публікації таких науковців, як Р.Маньковська [5] та І.Синельник [15], які розглядають «Ніч музеїв» у контексті прикладу музейної комунікації, наводять факти успішності цього заходу в Україні і світі. У статтях М.Князьської-Ханової [3] та Д.Корнилової [4] продемонстровано успішність проведення «Ночі музеїв» в Україні, на прикладі конкретних музеїв.

Мета статті $\epsilon$ довести ефективність акції «Ніч музеїв» як засобу залучення громадськості до музеїв та популяризації музейної спадщини серед пересічних громадян України і світу.

Викладення основного матеріалу. 31977 року 18 травня у світі відзначають Міжнародний день музеїв. 3 нагоди цієї події в останні декілька десятиліть більшість музеїв світу влаштовує цими днями так звану «Ніч музеїв», коли відвідувачам пропонують нічні екскурсії, майстер-класи, квести та участь у різних акціях. Причому плата за відвідування або не береться взагалі, або є доволі символічною.

Основна мета цієї акції - показати ресурс, можливості, потенціал сучасних музеїв, залучити до них молодь. В останні роки це свято стало традиційним для багатьох країн світу: зокрема, 2016 року «Ніч музеїв» відзначили майже 35 тисяч закладів культури зі 145 країн світу [8], 2017 року - понад 36 тисяч музеїв зі 157 країн світу [17], 2019 року 35 тисяч музеїв у понад 150 країнах, було проведено понад 5000 заходів й зроблено понад 50000 постів у соціальних мережах [16].

Цікаво, що в 1970-ті роки подібна акція мала назву «Весна музеїв». У 1997 році в Берліні вперше провели «Довгу ніч музеїв» (Lange Nacht der Museen). Відтоді цей художньо-просвітницький захід проводять у столиці Німеччини двічі на рік в останню суботу січня та серпня. Тоді адміністрація міста Берліна прийняла рішення не брати плати з відвідувачів музеїв, а екскурсії проводити до самого ранку. Ідея настільки припала до душі німцям, що наступного року до акції долучилося ще два десятки міст ФРН [2].

Сам Міжнародний день музеїв подібними заходами було вирішено відзначати в Парижі з 2001 року. Пізніше кожна акція отримала свою тематику, зокрема «П'ять відчуттів», «Таємні одкровення», «Історія та історії». Крім цих заходів, організовували також ярмарки, театралізовані вистави, маскаради та 
концерти. У 2005 році французи висунули ідею щорічного проведення Міжнародної музейно-виставкової, культурно-освітньої акції «Ніч музеїв», й того самого року цю ідею було затверджено Радою Європи [13].

32011 року Європейська ніч музеїв знайшла офіційного спонсора. Ним став IКОМ (ICOM) Міжнародна рада музеїв [8].

32003 року до акції долучилася Польща. Спершу лише 11 установ Варшави взяли участь у дійстві. Проте вже 2016 року «Ніч музеїв» провели в 252 культурних установах, 3 них лише 52 - музеї польської столиці. Рівно о 18:00 всі варшавські музеї зробили безкоштовний вхід на свої експозиції. В Галереї Фарас у Національному музеї читали лекцію про гоплітів та організовували квест на знання ранньохристиянського живопису, в Музеї Війська Польського пропонували ознайомитися зі зразками старовинного традиційного озброєння Польської армії; у Музеї історії польських євреїв POLIN можна було побачити світові інсталяції на тему дерев'яних синагог. 32009 року в Польщі до акції «Ніч музеїв» залучено інші установи, пов'язані зі сферою культури й не тільки з нею. Серед них - Варшавська станція водоочищення, Варшавське депо Мазовецької залізниці, Польська академія наук, Національна бібліотека, Національний стадіон Варшави, Польська агенція преси, прогулянкові катери на Віслі. У цей день можна відвідати навіть кабінет ректора Варшавського університету [10].

Цікаво, що не в усіх країнах «музейні ночі» проводять у травні. Зокрема, в Нідерландах Museum Night Amsterdam традиційно влаштовують у першу неділю листопада. Цього дня двері півсотні столичних музеїв відчинені з 19:00 до 02:00, організовують різні заходи типу гуртків, концертів, вистав та спеціальних турів, звісно, їжа та напої не заборонені [18]. У самому Берліні «Ніч музеїв» проводять двічі на рік - у січні та серпні [11]. В Естонії, наприклад, останній раз «Ніч музеїв» провели 29 серпня 2020 року (у 2021 році вирішили не проводити). Тема заходу - «Час уночі» [1].

Щороку Міжнародний день музеїв проводять під певною темою. Так 2017 року було обрано: «Музеї $\mathrm{i}$ суперечлива історія: розповідаючи про замовчуване» [8]. У 2018 році визначили «Гіперпов'язані музеї: нові підходи, нові суспільства» [17]. У 2019 році тема була - «Музеї як культурні хаби: майбутнє традиції» [8]. У 2021 році Міжнародна рада музеїв затвердила тему «Майбутнє музеїв: перевинайдення та переосмислення» [14]. До кожної з тем на сайті ІКОМ розміщують пояснювальну записку, в якій наголошують на тих аспектах проблеми, яку слід розкрити в поточному році.

Першим музеєм в Україні, що долучився до акції «Ніч музеїв», став Дніпропетровський національний історичний музей. Це сталося в ніч з 21 на 22 травня 2005 року, коли було проведено тематичну екскурсіювиставу під назвою «Людина і степ» [7]. Що стосується Житомирщини, то найраніше «Ніч музеїв» було організовано в Музеї космонавтики ім. С.П. Корольова у 2007 році [6]. 2008 року до всесвітньої акції долучилися музеї Києва, Львова, Одеси, Харкова та Феодосії [5, с. 78]. А от, наприклад, Чернігівський історичний музей імені В.В. Тарновського запрошує на «Ніч у музеї» з 2011 року. Гасло заходу: «Музей територія спілкування», однак майже щороку виокремлюються певні тематичні аспекти. Зокрема, «Музеї для сталого суспільства» (2015), «Музей і ландшафти» (2016), «Музей і суперечлива історія: розповідаючи про замовчуване» (2017) [15, с. 156].

Розглянемо, на які заходи запрошували музеї України в попередні роки в «Ніч музеїв». Наприклад, 2017 року в Києві пропонували відвідати:

- Київська фортеця - інтерактивна екскурсія «Прогулянка 3 бароном й баронесою фон Мюнхгаузен», вхід - 100 грн;

- Національний музей українського народного декоративного мистецтва - перегляд кінофільму «Катерина Білокур», перформанс «Про що скриплять музейні сундуки», дефіле моделей в авторських костюмах студентів спеціалізації «Художнє моделювання костюму», вхід - вільний;

- Літературно-меморіальний музей М.Булгакова - виставка, присвячена господареві будинку № 13 на Андріївському узвозі Василеві Павловичу Листовничому, вхід - вільний;

- Музей-квартира Павла Тичини - джазова музика та композиції 1920-х років, вхід - 200 грн;

- Музей історії Києва - дискусії, майстер-класи, лекції з історії та культури, розповіді про подорожі та стиль життя скандинавів, вхід - 200-250 грн [4].

Не менш цікаво було й в інших містах України. Зокрема, в Дніпрі 13 травня 2017 року, з 17:00 до 23:00, в Історичному музеї було представлено програму, присвячену невідомим сторінкам історії України. Кава, майстер-класи, конкурси й танці. Вартість квитка - 100 грн. Цього самого дня в Дніпровському технічному музеї провели нічну екскурсію під назвою «Машини часу». Відвідувачі мали змогу покататися на міліцейському ретроавтобусі, пригадати смак газованої води з вуличних автоматів, переглянути фільми на кіноапаратах класу «олдскул», пройти майстер-клас з токарного ремесла та петриківського розпису. В «Музеї українського живопису» за 50 грн гостей дивували магічною подорожжю «Лабіринт часу». Зокрема можна було переглянути виставу «Беркут» театру «Герць» та вогняний перформанс від Олени Шептицької. У Харкові до акції долучилося 28 галерей, музеїв та культурних центрів (для порівняння 2010 року лише вісім [12]). Так, у кінотеатрі «8 1/2» працював інтерактивний музей кіно 3 програмою про заборонені фільми. В артпідвалі Харківської муніципальної галереї відбувся хепенінг. 3 18:00 до 23:00 бажаючих відвідати всі ці заходи підвозив безкоштовний автобус. У Меджибожі «Ніч музеїв» проходила 
у фортеці. Гостей дійства запрошували до відреставрованого палацу, потім дивували рицарськими боями на мечах та театральними постановками. У Луцьку, Ужгороді, Острозі, Кам'янці-Подільському найцікавіші дійства також відбувалися на території замків [3]. У Чернігівському військово-історичному музеї було проведено демонстрацію фільмів з історії Японії, відкрито мінівиставку «Зброя Японії», організовано майстер-клас з оригамі; також відбувся показовий виступ членів історико-етнографічного клубу з військових змагань [15, с. 156].

Що стосується 2021 року, то, попри обмеження, пов'язані із COVID-19, вітчизняні музеї активно долучилися до акції «Ніч музеїв»:

- 18 травня в Національному музеї історії України було проведено театралізовану вечірню екскурсію з каганцями «Міфи музейних експонатів». Початок о 21:00. Саме о цій порі музейні духи (Дух Мізинського браслету, Дух кам'яної стели, Дух піфосу, Дух Ромашківського глека, Дух срібної фібули) стали розповідати фантастичні легенди. Відвідувачам пропонували взяти участь у майстер-класах та випробувати долю у безпрограшній лотереї. Вартість квитка - 250 грн;

- 18 травня Чернівецький обласний музей народної архітектури та побуту підготував нічну театралізовану екскурсію з яскравими персонажами і частуванням у корчмі. Відвідувачів скансену розважали мольфар, мельник та інші персонажі у виконанні акторів народного театру при Центральному будинку культури. Початок о 21:00. Вартість квитка - 160 грн;

- у Дніпропетровському національному історичному музеї ім. Д.І. Яворницького «Ніч музеїв» святкували 22 травня, з 18:00 до опівночі. Однак безпосередні заходи розпочалися ще вдень. Так з 14:00 до 16:00 проводилися безкоштовні майстер-класи з ліплення, малювання та розфарбовування писанок; 3 17:00 щопівгодини організовувалися екскурсії. Вартість квитка - 300 грн;

- у Чернігівському художньому музеї ім. Г.Галагана також 22 травня було організовано перформанс-презентацію колекції дизайнерського одягу Ольги Костюченко, мінівиставку дизайнерських капелюшків Валентини Свистун та проведено концерт «Весняний настрій» капели бандуристів імені Остапа Вересая. У програмі заходів зазначалися відкриття персональної виставки декоративноужиткового мистецтва Анатолія Семенцова «Коли Сонце було богом», лялькова казка-жарт «Принцесастрибунка», зустрічі, лекції та майстер-класи. Початок о 15:00, вхід - вільний;

- у Музеї Полтавської битви 28 травня було проведено нічну екскурсію «Міфи і факти поля Полтавської битви». У програмі заходу - спростування міфів поля Полтавської битви, пісочна анімація, фотографування в історичних костюмах. Кульмінацією дійства стало артилерійське шоу. Вартість квитка - 120 грн [9].

Наскільки успішними є подібні акції, напевно, можна судити з кількості відвідувачів. У 2013 році в Дніпропетровському національному історичному музеї ім. Д.І. Яворницького «Ніч музеїв» відвідало 1200 осіб, натомість у 2015 році - вже 2500 осіб [7]. Звісно, що до європейських музеӥв нам ще далеко. Наприклад, в «Ніч музеїв» популярні музеї Варшави приймають по 5 000-6 000 відвідувачів, а Варшавський університет - понад 10000 осіб [10].

Висновки. Проведення акції «Ніч музеїв» свідчить про тісний зв'язок українського культурного простору зі світовим. Розглядати цей захід слід виключно позитивно: навіть у провінційних містах молодь матиме змогу безкоштовно відвідати музеї, долучитися до прекрасного, мислити й творити разом із митцями. У такий спосіб музеї ще раз нагадають про себе й владі, яка не поспішає збільшувати фінансування цих культурних установ. 3 іншого боку, порівняно 3 країнами Європи, де до акції щороку долучається все більше і більше установ сфери культури, в Україні проведення заходу обмежується в основному лише музеями; не до кінця продуманими залишаються питання функціонування інфраструктури (робота наземного й підземного транспорту); недостатньою мірою проводиться реклама. А тому в музеї приходять найчастіше віддані відвідувачі та фахівці, а не широкий загал. Тож на майбутне музеям України, особливо провінційним, варто було б налагодити більш тісну комунікацію із відвідувачами через активну участь у різних проєктах, активніше залучати неурядові організації та спонсорів, співпрацювати з університетами, де здійснюється підготовка фахівців у сфері туризму.

Список використаної літератури:

1. 29 августа по всей Эстонии пройдет ночь музеев на тему «Время в ночи» [Электронный ресурс]. - Режим доступа : https://www.muuseumioo.ee/ru.

2. Длинная ночь музеев в Берлине [Электронный ресурс]. - Режим доступа : https://www.tourister.ru/world/europe/germany/city/berlin/museum/36509.

3. Князьская-Ханова М. Ночь музеев в Украине: куда будут пускать безплатно / М.Князьская-Ханова [Электронный ресурс]. - Режим доступа : https://kiev.segodnya.ua/kiev/kwheretogo/noch-muzeev-v-ukrainekuda-budut-puskat-besplatno-1020973.html.

4. Корнилова Д. Бесплатный вход, экскурсии до утра и концерты под звездами: гид по Ночи музеев в Киеве / Д.Корнилова [Электронный ресурс]. - Режим доступа : https://kiev.vgorode.ua/news/dosuh_y_eda/329313besplatnyi-vkhod-ekskursyy-do-utra-y-kontserty-pod-zvezdamy-hyd-po-nochy-muzeev-v-kyeve.

5. Маньковська Р. Сучасні музейні комунікації та перспективи їх розвитку / Р.Маньковська // Краєзнавство. 2013. - № 3. - C. 75-84. 
6. Мистецька акція «Ніч музеїв» [Електронний ресурс]. - Режим доступу : https://cosmosmuseum.info/nich-muzeiv/.

7. Ніч музеїв [Електронний ресурс]. - Режим доступу : https://gorod.dp.ua/afisha/event/35292.

8. Ніч музеїв [Електронний ресурс]. - Режим доступу : http://icom.in.ua/den-muzeyiv/.

9. Ніч музеїв в Україні 2021: ТОП 10 заходів [Електронний ресурс]. - Режим доступу : https://zruchno.travel/Publications/Entry/5785?lang=ua.

10. Ніч музеїв - карнавал культури [Електронний ресурс]. - Режим доступу : https://culture.pl/ru/article/nichmuzeyiv-karnaval-kulturi.

11. Ночь в музее: расписание для 20 стран [Электронный ресурс]. - Режим доступа : https://www.gq.ru/travels/noch-v-muzee-raspisanie-dlya-20-stran.

12. Ночь музеев - 2017: полная программа мероприятий [Электронный ресурс]. - Режим доступа : http://faqindecor.com/ru/noch-muzeev-2017-polnaya-programma-meropriyatij/.

13. Ночь музеев придумали в Берлине [Электронный ресурс]. - Режим доступа : http://www.studygerman.ru/support/lib/article73.html.

14. Процак X. 318 до 23 травня Львів святкує Міжнародний день музеїв / Х.Процак [Електронний ресурс]. Режим доступу : https://city-adm.lviv.ua/news/culture/285635-z-18-do-23-travnia-lviv-sviatkuie-mizhnarodnyiden-muzeiv.

15. Синельник I. Акція «Ніч у музеї» як зразок ефективної комунікації з відвідувачами (на прикладі Чернігівського історичного музею імені В.В. Тарновського / І.Синельник // Сіверянський літопис. - 2018. № 4. - C. $154-158$.

16. Celebrating the success of international museum day! [Електронний ресурс]. - Режим доступу : https://icom.museum/en/news/celebrating-the-success-of-international-museum-day.

17. International Museum Day 2018 [Електронний ресурс]. - Режим доступу : http://network.icom.museum/international-museum-day.

18. Museum Night Amsterdam [Електронний ресурс]. - Режим доступу : https://www.iamsterdam.com/en/see-anddo/whats-on/festivals/overview-cultural-festivals/museum-night-amsterdam.

\section{References:}

1. «29 avgusta po vsei Estonii proidet noch' muzeev na temu "Vremya v nochi"», [Online], available at: https://www.muuseumioo.ee/ru

2. «Dlinnaya noch' muzeev $\mathrm{v}$ Berline», [Online], available at: https://www.tourister.ru/world/europe/germany/city/berlin/museum/36509

3. Knyaz'skaya-Khanova, M., Noch' muzeev v Ukraine: kuda budut puskat' bezplatno, [Online], available at: https://kiev.segodnya.ua/kiev/kwheretogo/noch-muzeev-v-ukraine-kuda-budut-puskat-besplatno-1020973.html

4. Kornilova, D., Besplatnyi vkhod, ekskursii do utra i kontserty pod zvezdami: gid po Nochi muzeev v Kieve, [Online], available at: https://kiev.vgorode.ua/news/dosuh_y_eda/329313-besplatnyi-vkhod-ekskursyy-do-utra-y-kontsertypod-zvezdamy-hyd-po-nochy-muzeev-v-kyeve

5. Man'kovs'ka, R. (2013), «Suchasni muzejni komunikacii' ta perspektyvy i'h rozvytku», Krajeznavstvo, No. 3, pp. 75-84.

6. «Mystec'ka akcija “Nich muzei'v”», [Online], available at: https://cosmosmuseum.info/nich-muzeiv/

7. «Nich muzei'v», [Online], available at: https://gorod.dp.ua/afisha/event/35292

8. «Nich muzei'v», [Online], available at: http://icom.in.ua/den-muzeyiv/

9. «Nich muzei'v v Ukrai'ni 2021: TOP 10 zahodiv», [Online], available at: https://zruchno.travel/Publications/Entry/5785?lang=ua

10. «Nich muzei'v - karnaval kul'tury», [Online], available at: https://culture.pl/ru/article/nich-muzeyiv-karnaval-kulturi

11. «Noch' v muzee: raspisanie dlya 20 stran», [Online], available at: https://www.gq.ru/travels/noch-v-muzeeraspisanie-dlya-20-stran

12. «Noch' muzeev - 2017: polnaya programma meropriyatii», [Online], available at: http://faqindecor.com/ru/nochmuzeev-2017-polnaya-programma-meropriyatij/

13. «Noch' muzeev pridumali v Berline», [Online], available at: http://www.studygerman.ru/support/lib/article73.html.

14. Procak, H., Z 18 do 23 travnja L'viv svjatkuje Mizhnarodnyj den' muzei'v, [Online], available at: https://cityadm.lviv.ua/news/culture/285635-z-18-do-23-travnia-lviv-sviatkuie-mizhnarodnyi-den-muzeiv

15. Synel'nyk, I. (2018), «Akcija «Nich u muzei'» jak zrazok efektyvnoi' komunikacii' z vidviduvachamy (na prykladi Chernigivs'kogo istorychnogo muzeju imeni V.V. Tarnovs'kogo», Siverjans'kyj litopys, No. 4, pp. 154-158.

16. «Celebrating the success of international museum day!», [Online], available at: https://icom.museum/en/news/celebrating-the-success-of-international-museum-day

17. «International Museum Day 2018», [Online], available at: http://network.icom.museum/international-museum-day

18. «Museum Night Amsterdam», [Online], available at: https://www.iamsterdam.com/en/see-and-do/whatson/festivals/overview-cultural-festivals/museum-night-amsterdam

Кругляк Марина Едуардівна - кандидат історичних наук, доцент, доцент кафедри туризму та готельно-ресторанної справи Державного університету «Житомирська політехніка».

https:// orcid.org/0000-0003-3837-0982.

Наукові інтереси:

- $\quad$ туристичне краєзнавство; туристичне країнознавство;

- світовий туризм; музейна справа.

E-mail: marinakrugljak@ukr.net. 